\title{
Neurological manifestations associated with SARS-CoV-2 - A review
}

\author{
David A. Aguilar-Andino* \\ Escuela Universitaria de Ciencias Médicas de la UNAH-VS. San Pedro Sula, Cortés, Honduras
}

\begin{abstract}
A new virus belonging to the Coronavirus (COV) family burst into the Wuhan region of China causing severe acute respiratory syndrome of high lethality. COV not only is pathogenic that mainly affects the human respiratory system but also has neuroinvasive capabilities. The transmission mechanism is person-to-person; also air propagation and other mechanisms have been described. The main entrance mechanism is through the binding of the virus' $S$ protein with angiotensin-converting enzyme receptors, these are present in multiple systems including the nervous system. The spread of SARS-CoV-2 in systemic circulation or through the cribriform plaque of the ethmoid bone during an early or later phase of infection can lead to brain involvement. Multiple cases with general neurological manifestations have been reported worldwide, such as headache and confusion, but also more specific cases of cerebrovascular disease, encephalitis, and anosmia, among others described in this review. Specialists are encouraged, within patients with neurological manifestations, to investigate epidemiological links to establish the relationship between a neurological manifestation probably secondary to COVID-19. Diagnostic tests in patients with such manifestations are recommended to establish an association. It is recommended to conduct studies oriented to the different neurological manifestations, and also to clinicians to stay alert with them to improve both the evolution and the prognosis of the patient.
\end{abstract}

Key words: Neurotropism. COVID-19. SARS-CoV-2. Manifestations. Central nervous system.

\section{Manifestaciones neurologicas asociadas a SARS-CoV-2: una revisión bibliografica}

\section{Resumen}

Un nuevo virus perteneciente a la familia de los coronavirus irrumpió como agente patógeno en la región de Wuhan, China provocando un síndrome respiratorio agudo severo de alta letalidad. El coronavirus es patógeno que principalmente afecta al sistema respiratorio humano, pero también tiene capacidades neuroinvasivas. El mecanismo de transmisión es de persona a persona, también la propagación aérea y otros mecanismos se han descrito. El principal mecanismo de entrada es a través de la unión de la proteína $S$ del virus con los receptores de enzima convertidora de angiotensina, estos presentes en múltiples sistemas incluyendo el sistema nervioso. La diseminación de SARS-CoV-2 en la circulación sistémica o a través de la placa cribiforme del hueso etmoides durante una fase temprana o posterior de la infección puede conducir a la afectación cerebral. Múltiples casos con manifestaciones neurológicas generales han sido reportados a nivel mundial, como ser cefalea y confusión, pero también casos más específicos de enfermedad cerebrovascular, encefalitis, anosmia entre otros

\section{Correspondence:}

*David A. Aguilar-Andino

E-mail: aguilar54david@gmail.com
Available online: 05-08-2020

Rev Mex Neuroci. 2020;21(4):150-157

www.revmexneurociencia.com 1665-5044/ @ 2020 Academia Mexicana de Neurología A.C. Published by Permanyer. This is an open access article under the CC BY-NC-ND license (http://creativecommons.org/licenses/by-nc-nd/4.0/). 
que son descritos en esta revisión. Se recomienda a los especialistas que, en aquellos pacientes con manifestaciones neurológicas, que se investigue acerca de nexos epidemiológicos, para así establecer el vínculo entre una manifestación neurológica probablemente secundaria a COVID-19. Se recomienda realizar las pruebas de diagnóstico, en pacientes con dichas manifestaciones, para establecer una asociación. Se recomienda realizar estudios orientados a las diferentes manifestaciones neurológicas, y también a los clínicos a mantenerse alerta con las mismas para mejorar tanto la evolución como el pronóstico del paciente.

Palabras clave: Neurotropismo. COVID-19. SARS-CoV-2. Manifestaciones. SNC.

\section{Introduction}

In December 2019, a new virus belonging to the Coronavirus (CoV) family broke in as a pathogen in China's Wuhan region causing high-lethal severe acute respiratory syndrome (SARS). The World Health Organization (WHO) gave it the name SARS-CoV-2 given its similarity virologically and also in its clinical expression with SARS-CoV (229E [HCoV-229E]), responsible for a syndrome of similar characteristics also originating in animal markets in China in $2003^{1}$. As of 24 February 2020 , more than 80,000 confirmed cases have been reported, including more than 2700 deaths worldwide, affecting at least 37 countries. The $\mathrm{WHO}$ declared it a global health emergency by the end of January $2020^{2}$.

CoVs are members of the family Coronaviridae, wrapped viruses that possess extraordinarily large single-chain RNA genomes ranging from 26 to $32 \mathrm{~kb}$ in length ${ }^{3}$. An unknown that continues to be investigated is the recognition of the zoonotic origin of said virus, but due to its close similarity to bat CoVs, it is likely that these are the primary reservoir of the virus, since with the reappearance of this new class of CoV various studies was performed and SARS-CoV-2 was found to be $96 \%$ identical at the genome level to a bat CoV; the same study revealed that the virus belongs to the SARS-CoV species. This is how SARS-CoV is speculated to have been transmitted to humans from exotic animals in markets in the outbreak 18 years ago, while Middle East respiratory syndrome coronavirus (MERSCoV) was transmitted from camels to humans ${ }^{4}$.

Transmission from one person to another has been demonstrated, and the transmission mechanism is known to be by respiratory drops generated during coughs and sneezes by symptomatic patients, but may also occur by asymptomatic individuals and before symptoms onset ${ }^{5}$. Anderson et al. suggest transmission through aerosols predominantly $<1 \mu \mathrm{m}$, produced when speaking or with normal breathing by asymptomatic patients. It also suggests that aerosols may be a long-distance transmission vehicle due to suspension of aerosols in the air for several hours. All of the above related to survival time and distances, virus concentrations, effects of temperature and humidity, and the implications of aerosol size and viral load in contact with the respiratory tract ${ }^{6}$. Chan et al. report findings that suggest the transmission of person to person and that intercity spread of SARSCoV-2 by air is possible ${ }^{7}$.

In a cohort study conducted by $\mathrm{Li}$ et al. ${ }^{8}$, SARSCoV-2 has been reported in semen of the 38 patients undergoing the study ${ }^{8}$. Fecal-oral transmission has also been suggested and a vertical transmission mechanism has recently been proposed ${ }^{9}$.

SARS-CoV-2 uses the angiotensin-converting enzyme (ACE2) as its main receptor, which is widely expressed in vascular endothelium, respiratory epithelium, alveolar monocytes, macrophages, and neurons (Fig. 1). Later in the course of the disease, COVID-19 resembles SARS in terms of viral replication in the lower respiratory tract, and generates secondary viremia, followed by an extensive attack on target organs expressing ECA2, such as the heart, kidney, gastrointestinal tract, and vast distal vasculature ${ }^{10}$.

The clinical characteristics of COVID-19 are varied, ranging from asymptomatic state to acute respiratory distress syndrome and multiorgan dysfunction ${ }^{11}$. Symptoms that have been reported in particular are fever, dry cough, dyspnea, myalgia and fatigue, less frequent confusion, headache, pharyngeal pain, rhinorrhea, abdominal pain, diarrhea, nausea, and vomiting ${ }^{9}$.

$\mathrm{CoV}$ is one of the main viruses that mainly affects the human respiratory system, but it also has neuroinvasive capabilities and can spread from the respiratory tract to the central nervous system $(\mathrm{CNS})^{12}$.

In January 2020, Chen et al. published a retrospective analysis based on 99 patients diagnosed with SARS-CoV-2 pneumonia at a hospital in Wuhan, China. Neurological symptoms presented were confusion (9\%) and headache $(8 \%)^{13}$. In addition, different studies have been reported that assert neurological manifestations secondary to SARS-CoV-2, so attention should be paid 


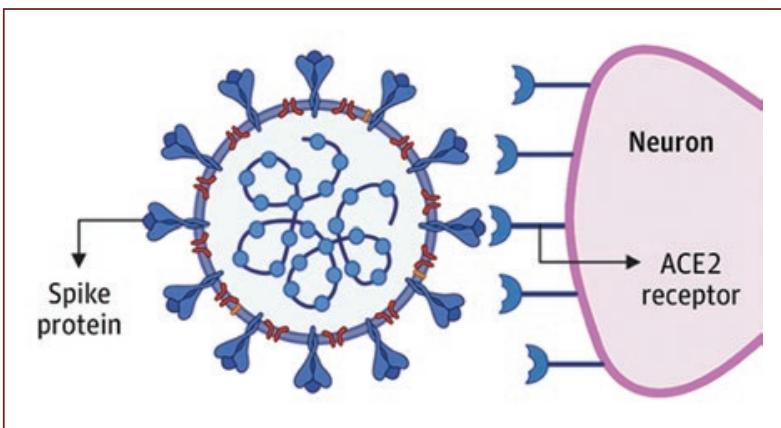

Figure 1. Angiotensin-converting enzyme (ACE)-2 receptors at a medullary junction to the SPIKE protein in severe acute respiratory syndrome coronavirus 2 . Emerging data suggest that ACE 2 receptors are expressed in multiple regions of the human brain, including the motor cortex, posterior cingulate cortex, ventricles, Nigri substance, olfactory bulb, medium temporal turn, ventrolateral marrow, solitary tract nucleus, and vagus dorsal motor nucleus. (taken from Zubair et al. ${ }^{28}$ ).

to these manifestations because they may affect the prognosis and evolution of the patient.

\section{Neurotropism's background}

It is currently known that CoVs are not always limited to the respiratory tract and that they can also invade CNS by inducing neurological diseases. This neuroinvasive capacity of CoVs has been documented almost for all COVs, including SARS-CoV, MERS-CoV, HCoV229E, HCoV-OC43, mouse hepatitis virus, and porcine hemagglutinating encephalomyelitis ${ }^{14}$.

The SARS pandemic that occurred in 2002 detected sequences of the virus genome in the brain of all SARS deceased autopsies with light microscopy, electron microscopy, and real-time reverse transcription-polymerase chain reaction (rRT-PCR). The signals were limited to the cytoplasm of numerous neurons in the hypothalamus and cortex ${ }^{15}$. The edema and scattered red degeneration of neurons were present in the brains of six of the eight confirmed cases of SARS. Viral SARS sequences and pathological changes were not present in the brain of unconfirmed cases or control cases ${ }^{15}$. Likewise, patients with acute SARS-CoV disease have also demonstrated the presence of the virus in cerebrospinal fluid ${ }^{16}$.

Overall, neuroinvasive ability has been shown to be a common feature of COVs. Considering the high similarity between SARS-CoV and SARS-CoV-2, SARSCoV-2 is also likely to have similar potential ${ }^{14}$.
The spread of SARS-CoV-2 in systemic circulation or through the cribriform plaque of the ethmoid bone during an early or later stage of infection can lead to brain involvement as has been reported in the past for SARS-CoV ${ }^{16}$. The latter can be supported by the fact that in the study of Mao et al., some patients had hyposmia ${ }^{17}$.

The presence of the COVID-19 virus in the general circulation allows it to, understandably, move to brain circulation where the slow flow of blood within microcirculation could be one of the factors that can facilitate the interaction of the spike protein (protein S) of the SARSCoV-2 virus with ACE-2 receptors ${ }^{16}$. These receptors are known to be expressed in the lungs, heart, kidneys, intestines, brain, and testicles by converting these different organs into possible SARS-CoV-2 targets $^{16}$.

\section{CNS manifestations}

\section{Inespecific manifestations}

SARS-CoV-2 has been shown to exhibit non-specific neurological manifestations, which are well unknown whether they can be caused directly or indirectly by the virus. In a study by Mao et al., 214 patients, 88 (41.1\%) and $126(58.9 \%)$ they were not serious. Of these, 78 (36.4\%) neurological manifestations involve CNS, peripheral nervous system, and skeletal muscles. Severe patients were more likely to develop neurological symptoms, especially acute cerebrovascular disease, altered consciousness, and muscle injuries ${ }^{17,18}$. It should be emphasized that headache is the most common neurological symptom in Wuhan, China according to study conducted by Guan et al. ${ }^{19}$.

Furthermore, in a study conducted in two different intensive care unit (ICU) in France, 58 patients reported neurological findings; agitation was present in 40 patients $(69 \%)$. A total of 26 out of 40 patients were observed to have confusion under the ICU Confusion Assessment Method. Diffuse signs of the corticoespinal tract such as muscle stretching hyperreflexia, aquileo clonus, and bilateral Babinski sign were present in 39 patients $(67 \%)$. Of the patients who had been discharged, 15 out of 45 (33\%) had a dysexecutive syndrome that consisted of inattention, disorientation, or poorly organized movements in response to the command $^{20}$.

These neurological manifestations have also been reported in Latin America. In Chile, a study was conducted with 922 positive cases (Table 1), of which 597 $(64.8 \%)$ headache as a cardinal symptom, while only 
Table 1. Main clinical findings in the first 922 cases of COVID 19 in Chile

\begin{tabular}{|l|c|c|}
\hline Síntomas & $\mathbf{n}$ & $\%$ \\
\hline Headache & 597 & 64.8 \\
\hline Dyspnea & 498 & 54.0 \\
\hline Cough & 452 & 49.0 \\
\hline Thoracic pain & 407 & 44.1 \\
\hline Fever & 78 & 8.5 \\
\hline Abdominal pain & 41 & 4.4 \\
\hline Myalgias & 32 & 3.5 \\
\hline
\end{tabular}

Adapted from Rodriguez-Morales et al., $2020^{21}$.

$8.5 \%$ and $49.0 \%$ had fever and cough, respectively, among other symptoms. The presence of headache in most of these patients may suggest the potential neurotropism and neurovirulence of SARS-CoV-2 as seen in other naturally neurotropic human CoVs such as SARS-CoV and HCoV-OC43 and -229E ${ }^{21}$.

Several observational studies have looked at symptoms of the disease, but few have addressed neurological symptoms that go beyond headache and confusion ${ }^{22}$.

\section{Meningitis and encephalitis}

The first case of aseptic encephalitis was reported in a 24-year-old patient, brought to the emergency by an ambulance due to a seizure accompanied by unconsciousness, presenting multiple generalized tonic-clonic epileptic seizures, and obvious neck stiffness. It was taken both nasopharyngeal and cerebral spinal fluid (CSF) samples and was diagnosed using RT-PCR technique by finding SARS-CoV-2 RNA in cerebrospinal fluid ${ }^{23}$.

Interestingly, imaging findings were also found in this patient, reporting a brain magnetic resonance imaging (MRI) with hyperintensity along the wall of the right lateral ventricle and hyperintense signal changes in the right mesial temporal lobe and hippocampus, suggesting the possibility of SARS-CoV-2 meningitis ${ }^{23}$.

In the current pandemic, Xiang et al.'s team, the Beijing Ditan Hospital confirmed the presence of SARS-CoV-2 virus in cerebrospinal fluid in patients positive for COVID-19. The finding was made using genomic sequencing techniques, as well as clinically confirming viral encephalitis in patients. This provides a solid foundation for considering CoVs as causing encephalitis ${ }^{18}$.
Positive COVID-19 patients have been reported, which usually present a clinical picture of meningitis/encephalitis, but with CSF RT-PCR tests for SARS-CoV-2 negative. Some authors argue that this happens because of the low inoculum that can occur in the CSF.

This is the case of a 64-year-old patient, who at the neurological examination indicated that the patient was impaired in mental state, with an alternating consciousness between lethargy and irritability. Both lower limbs showed positive ankle clonus, which was more pronounced in the left limb. The lower left limb was positive for Babinski's sign and Chaddock's sign; the lower right limb was suspected positive for Chaddock's sign. He also showed meningeous signs ${ }^{24}$.

There is also a positive patient for COVID-19 who has impaired consciousness accompanied by marked meningeous signs and Babinski's sign. After a thorough neurological evaluation by experts, the diagnosis of SARS-associated encephalitis CoV-2 was established, even though the CSF sample test tested negative for SARS-COV-2 ${ }^{25}$.

\section{Encephalopathy}

Encephalopathy is a transient brain dysfunction syndrome that manifests as an acute or subacute affectation of the level of consciousness. COVID-19-associated encephalopathy may be due to toxic and metabolic causes, and the effect of hypoxia or drugs. Another associated indirect mechanism is the presence of subclinical crises ${ }^{26}$. Encephalopathy is a demonstration of how CNS circuits responsible for arousal, perception and focus are distributed and how are susceptible to infectious, toxic, or metabolic systemic disorders. The CNS's response to such disorders is often relatively acute, and a variety of different irritants often produce the same nonspecific behavioral reactions ${ }^{27}$.

Elderly patients with chronic diseases have an increased risk of mental state disturbance in the acute infection environment. One of the possible etiological mechanisms of encephalopathy could be due to the cytokine storm which along with other comorbidities and risk factors contributes significantly to toxic metabolic encephalopathy in severe cases ${ }^{28}$.

Mehta et al. ${ }^{29}$ describes a cytokine profile associated with the severity of COVID-19, characterized by an increase in interleukin (IL)-2, IL-6, IL-7, granulocyte colony stimulating factor, interferon-gamma inducible protein 10, 1-necroattract monocyte protein, 1-alpha inflammatory macrophage protein, and necrosis tumor factor. This cytokine storm in combination with different 
comorbidities and metabolic imbalances could be the cause of encephalopathy.

Because COVID-19 affects more elderly and those with pre-existing conditions, patients with the previous neurological conditions and acute respiratory symptoms have an increased risk of encephalopathy at baseline ${ }^{17,30}$. One study reported an electroencephalogram that showed diffuse slow waves in the bilateral temporal region in the patient's studied ${ }^{30}$.

\section{Acute necrotizing encephalopathy (ANE)}

A case of ANE hemorrhagic has also been reported in a patient diagnosed with COVID-19 who had symptoms of fever, cough, and altered mental state. Diagnosis was performed by detection of SARS-CoV-2 by PCR-TR in a nasopharyngeal sample. Brain computed tomography (CT) detected a symmetrical, bilateral hypodense area in the medial thalamic nucleus. The MRI showed hemorrhagic lesions that enhanced after contrast, multifocal and symmetrical disposition, in annular form in both thalamus, insula, and the medial region of the temporal lobes ${ }^{31}$.

ANE is a rare complication of influenza and other infections and has been related to intracranial cytokine storms, which result in decay of the blood-brain barrier, but without direct viral invasion or parainfectious demyelination ${ }^{32}$. Accumulated evidence suggests that a subgroup of severe patients with COVID-19 may have cytokine storm syndrome ${ }^{29}$.

\section{Cerebrovascular disease}

The mechanism by which SARS-CoV-2 virus enters the system by binding the $S$ protein to ACE 2 receptors is known. ACE 2 through a signaling mechanism lowers blood pressure. Since the expression of these receptors is decreased in hypertensive patients, the ability of ACE2 to reduce blood pressure is affected in these patients. After SARS-CoV-2 infection, the expression and function of ACE2 proteins are reduced ${ }^{33}$. As a second line of evidence suggesting that SARS-CoV-2 infection may induce brain hemorrhage, patients with COVID-19 often suffer from coagulopathy and prolonged prothrombin time, which also contributes to secondary brain haemorrhage ${ }^{33}$.

In addition, patients in critical condition with severe SARS-CoV-2 infections often show elevated levels of D-dimer ${ }^{34}$ and severe reduction of platelets, which can make these patients prone to acute cerebrovascular events ${ }^{15}$.
In a retrospective study in Wuhan, China, it was reported that 13 out of 221 COVID-19 patients developed CVD after infection; 11 (5\%) developed acute ischemic stroke, $1(0-5 \%)$ cerebral venous sinus thrombosis, and $1(0-5 \%)$ brain hemorrhage. Patients with CVD had elderly and cardiovascular and cerebrovascular risk factors. Importantly, 11 of the 13 CVD were severe patients with SARS-CoV-2 infection, suggesting that severe infection may be an indicator of CVD, especially acute ischemic stroke. Older patients with COVID-19 may be more likely to develop CVD and more attention should be paid to older patients with cerebrovascular risk factors. Mortality was $38 \%{ }^{35}$.

The Mao et al. series describes five patients with stroke $(80 \%$ ischemic), who had severe forms of COVID-19, with increased levels of D-dimer, thrombocytopenia, and multiple organ involvement ${ }^{17}$.

Oxley et al. report the case of five patients under the age of 50, positive for COVID-19 in New York City, who suffered an ischemic cerebrovascular event ${ }^{36}$. Some have symptoms such as impaired consciousness, lethargy, and headache. All patients reported involvement of large brain vessels such as the internal carotid artery, the middle cerebral artery, and the posterior cerebral artery.

\section{Anosmia, hyposmia, and dysgeusia}

Although SARS-CoV-2 has many similarities to SARS-CoV and MERS, clinical data reveal differential characteristics, including olfactory alterations and hallucinations; these symptoms have not been reported in patients with SARS-CoV or MERS-CoV infection ${ }^{22}$.

Several countries, including Germany, the United Kingdom, and Italy, have reported an increasing number of neurological manifestations such as anosmia (loss of the ability to detect one or more odors, temporary, or permanent), hyposmia (decreased sensitivity to some or all odors), ageusia (loss of taste functions), dysgeusia, or parageusia (the distortion of taste), and hypogeusia (decreased sensitivity to taste) in patients with confirmed SARS-CoV-2 infection ${ }^{21}$.

The mechanism of neuroinvasion through the cribriform plate to the olfactory nerve, besides from being an entry mechanism to the CNS, is believed to affect the sensory capacity of the olfactory nerve. A recent study showed that nasal epithelial cells show a very high expression of ACE 2 receptors ${ }^{37}$ within the SARSCoV-2 infection, allowing a wide viral entry ${ }^{38}$. SARS-CoV has demonstrated, in a mouse model, transneuronal penetration through the olfactory bulb ${ }^{14,39}$. 
In a European multicenter study conducted by Lechien et al. 357 patients (85.6\%) out of a total of 417 patients interviewed, had infection-related olfactory dysfunction. Among them, 284 (79.6\%) patient had anosmia and $73(20.4 \%)$ were hypostomatic. Fantosmia and parosmia account for $12.6 \%$ and $32.4 \%$ of patients during the course of the disease, respectively ${ }^{40}$. In the above-mentioned study, taste disturbances have also been reported, a total of 342 patients $(88.8 \%)$ reported taste disorders, which was characterized by the deterioration of the following four flavor modalities: salty, sweet, bitter, and acidic. Taste dysfunction consisted of a reduced/discontinued or distorted capacity to identify flavors in $78.9 \%$ and $21.1 \%$ of patients, respectively ${ }^{40}$.

The cause of dysgeusia is not yet very well established, however, in one study, a high expression of ACE 2 receptors was found in the epithelium of the tongue ${ }^{41}$. Animal studies show the expression of ACE 2 receptors in the solitary tract nucleus ${ }^{42}$ which could point to the central cause of dysgeusia and a possible neuroinvasive route by continuous retrograde axonal transport in humans ${ }^{43}$.

\section{Periferic nervous system manifestations}

\section{Guillain-Barre syndrome (GBS)}

The first case of GBS was reported, being a 61-yearold woman who had acute leg weakness and fatigue, which progressively advanced from the first day of initial symptoms. She returned from Wuhan on January 19, but denied having submitted COVID-19 compliant clinic. She was approached through a neurological examination that revealed symmetrical weakness (Medical Research Council Grade 4/5) and arreflexia in both legs and feet. Her symptoms progressed after 3 days of her admission. Muscle strength was $4 / 5$ grade on both arms and hands and $3 / 5$ on both legs and feet. CSF showed (5-10/L, normal: 0-8-10/L) and increased protein level $(124 \mathrm{mg} /$ $\mathrm{dL}$, normal: $8-43 \mathrm{mg} / \mathrm{dL}$ ). Nerve conduction studies (day 5) showed delayed distal latencies and absent F-waves in early course, supporting demyelinating neuropathy. On day 8 of disease evolution (January 30 ), the patient developed dry cough and a fever of $38.2^{\circ} \mathrm{C}$. Chest CT showed ground-glass opacities in both lungs. Oropharyngeal swabs were positive for SARS-CoV-2 on RT-PCR assay. Furthermore, she was diagnosed with GBS and was given immunoglobulin intravenously ${ }^{44}$.
It is also the case of a 76-year-old woman, transferred to the Navarra Hospital Complex for presenting a 10-day picture of the evolution of lumbar pain radiated to the back of both legs and progressive tetraparesis with distal onset paresthesias. Eight days before the beginning of the clinical manifestation, he had started with cough and fever without dyspnea, $72 \mathrm{~h}$ of evolution, having been treated with amoxicillin-clavulanic and azithromycin. PCR test was performed for SARSCoV-2 detection with a positive result ${ }^{45}$.

Even more characteristic cases of GBS have been reported, such as the report of a case of Miller Fisher syndrome and the case of a patient with multiple cranial neuropathies, both associated with COVID-1946.

\section{Transverse myelitis}

Transverse myelitis includes a pathologically heterogeneous syndrome characterized by acute or subacute spinal dysfunction resulting in paresis, a sensory level, and an autonomic impairment (bladder, bowel, and sexual impairment) below the level of the injury ${ }^{47}$.

A 66-year-old man with COVID-19 was admitted with acute flaccid bilateral lower extremity paralysis and urinary and intestinal incontinence. All serum microbiological test results were negative, except SARS-CoV-2 nucleic acid tests. Clinical findings indicated acute post-infectious myelitis. He was treated with ganciclovir, lopinavir/ritonavir, moxifloxacin, dexamethasone, human immunoglobulin, and mecobalamin. With a diagnosis of acute post-infectious myelitis and comprehensive treatment, bilateral lower limb paralysis improved ${ }^{48}$.

\section{Discussion}

SARS-CoV-2 has been shown not only to be an injury to the respiratory system, affectation of different systems but has also been reported, and one of the most affected is the nervous system. The mechanisms, direct or indirect, by which many of the above manifestations are caused by COVID-19, are unknown. There is evidence of a close relationship between the onset of neurological symptoms and a history of viral infection. General symptoms such as headache or a state of confusion in a confirmed COVID-19 patient should alert the clinician, and always keep in mind the likely onset of a manifestation or eventuality that compromises the patient's prognosis.

Detection and diagnosis of COVID-19 should be rapid and accurate to reduce the rate of contagion inside and outside hospital institutions. Specialists in the area of 
neurology are advised to be those patients with manifestations that guide a neurological pathology, to supplement the clinic with epidemiology in search of epidemiological links or risk factors in these patients, to establish the link between a neurological manifestation probably secondary to COVID-19. Due to the large percentage of asymptomatic patients today, it is recommended to perform current diagnostic tests such as RTPCR, rRT-PCR, and reverse transcription loop mediated isothermal amplification ${ }^{49}$. Also take all biosecurity measures recommended by the Centers for Disease Control ${ }^{50}$.

Once the diagnosis is established, Natoli et al. recommend that a record containing epidemiological data should be taken into account in patients with neurological manifestation associated with COVID-19 to fully understand whether and to what extent SARS-CoV-2 infections may cause CNS involvement. Also measure the viral load of SARS-CoV-2 in CSF in symptomatic and asymptomatic patients, for comparison. Finally, conduct research through autopsies to develop a characterization and find a distribution of the virus in different tissues, in this way, the neuropathological consequences can be determined ${ }^{51}$.

\section{Conclusion}

SARS-CoV-2 has demonstrated great neuroinvasive ability. A neurological complication added to a disease such as COVID-19 can turn the patient's evolution and prognosis into something bleak, not to mention the possible consequences that it may leave. The mechanism by which many of the above manifestations are caused by COVID-19 is unknown, but there is evidence of a close relationship between the onset of neurological symptoms and a history of viral infection. Studies aimed at establishing physical mechanisms of these manifestations are recommended to improve both the patient's evolution and prognosis.

\section{Funding}

This research has not received any specific grants from agencies in the public, commercial, or non-profit sectors.

\section{Conflicts of interest}

None.

\section{Ethical disclosures}

Protection of human and animal subjects. The authors declare that no experiments were performed on humans or animals for this study.

Confidentiality of data. The authors declare that they have followed the protocols of their work center on the publication of patient data.

Right to privacy and informed consent. The authors have obtained the written informed consent of the patients or subjects mentioned in the article. The corresponding author is in possession of this document.

\section{References}

1. Serrano-Castro PJ, Estivill-Torrús G, Cabezudo-García P, Reyes-Bueno JA, Petersen NC, Aguilar-Castillo MJ, et al. Influencia de la infección SARS-Cov2 sobre enfermedades neurodegenerativas y neuropsiquiátricas: una pandemia demorada? Impact of SARS-CoV-2 infection on neurodegenerative and neuropsychiatric diseases: a delayed pandemic? Neurología. 2020;35:245-51.

2. Yuen KS, Ye ZW, Fung SY, Chan CP, Jin DY. SARS-CoV-2 and COVID-19: the most important research questions. Cell Biosci. 2020;10:40.

3. Zheng J. SARS-CoV-2: an emerging coronavirus that causes a global threat. Int J Biol Sci. 2020;16:1678-85.

4. Palacios Cruz M, Santos E, Velázquez Cervantes MA, León Juárez M. COVID-19, a worldwide public health emergency. Rev Clin Esp. 2020;S0014-2565(20)30092-8:1-7.

5. Rothe C, Schunk M, Sothmann P, Bretzel G, Froeschl G, Wallrauch C, et al. Transmission of 2019-nCoV infection from an asymptomatic contact in Germany. N Engl J Med. 2020;382:970-1.

6. Anderson EL, Turnham P, Griffin JR, Clarke CC. Consideration of the aerosol transmission for COVID-19 and public health. Risk Anal. 2020;40:902-7.

7. Chan JF, Yuan S, Kok KH, To KK, Chu H, Yang J, et al. A familial cluster of pneumonia associated with the 2019 novel coronavirus indicating person-to-person transmission: a study of a family cluster. Lancet. 2020;395:514-23.

8. Li D, Jin M, Bao P, Zhao W, Zhang S. Clinical characteristics and results of semen tests among men with coronavirus disease 2019. JAMA Netw Open. 2020;3:e208292.

9. Miranda-Novales MG, Vargas-Almanza I, Aragón-Nogales R. COVID-19 por SARS-CoV-2: la nueva emergencia de salud. Rev Mex Pediatr. 2019:86:213-8.

10. Cao W, Li T. COVID-19: towards understanding of pathogenesis. Cell Res. 2020;30:367-9.

11. Singhal T. A review of coronavirus disease-2019 (COVID-19). Indian J Pediatr. 2020:87:281-6.

12. Asadi-Pooya AA, Simani L. Central nervous system manifestations of COVID-19: a systematic review. J Neurol Sci. 2020;413:116832.

13. Cardona GC, Pájaro LD, Marzola ID, Villegas YR, Salazar LR. Neurotropism of SARS-CoV 2: mechanisms and manifestations. J Neurol Sci. 2020;412:116824.

14. Li YC, Bai WZ, Hashikawa T. The neuroinvasive potential of SARS-CoV2 may play a role in the respiratory failure of COVID-19 patients. J Med Virol. 2020;92:552-5.

15. Gu J, Gong E, Zhang B, Zheng J, Gao Z, Zhong Y, et al. Multiple organ infection and the pathogenesis of SARS. J Exp Med. 2005;202:415-24.

16. Baig AM, Khaleeq A, Ali U, Syeda H. Evidence of the COVID-19 virus targeting the CNS: tissue distribution, host-virus interaction, and proposed neurotropic mechanisms. ACS Chem Neurosci. 2020;11:995-8.

17. Mao L, Wang M, Chen S, He Q, Chang J, Hong C, et al. Neurological manifestations of hospitalized patients with COVID-19 in Wuhan, China: a retrospective case series study. MedRxiv. 2020. Disponible en: https:// www.medrxiv.org/content/early/2020/02/25/2020.02.22.20026500.

18. Wu Y, Xu X, Chen Z, Duan J, Hashimoto K, Yang L, et al. Nervous system involvement after infection with COVID-19 and other coronaviruses. Brain Behav Immun. 2020 [Epub ahead of print]

19. Guan WJ, Ni ZY, Hu Y, Liang WH, Ou CQ, He JX, et al. Clinical characteristics of coronavirus disease 2019 in China. N Engl J Med. 2020;382:1708-20.

20. Helms J, Kremer S, Merdji H, Clere-Jehl R, Schenck M, Kummerlen C et al. Neurologic features in severe SARS-CoV-2 infection. N Engl J Med. 2020;382:2268-70 


\section{D.A. Aguilar-Andino: SARS-COV-2 and its neurological manifestations}

21. Rodriguez-Morales AJ, Rodriguez-Morales AG, Méndez CA, Hernández-Botero S. Tracing new clinical manifestations in patients with $\mathrm{CO}$ VID-19 in Chile and its potential relationship with the SARS-CoV-2 divergence. Curr Trop Med Rep. 2020;2020:1-4.

22. Matías-Guiu J, Gomez-Pinedo U, Montero-Escribano P, Gomez-Iglesias P, Porta-Etessam J, Matias-Guiu JA. Should we expect neurological symptoms in the SARS-CoV-2 epidemic? Neurología. 2020;35:170-5

23. Moriguchi T, Harii N, Goto J, Harada D, Sugawara H, Takamino J, et al A first case of meningitis/encephalitis associated with SARS-coronavirus-2. Int J Infect Dis. 2020;94:55-8.

24. Yin R, Feng W, Wang T, Chen G, Wu T, Chen D, et al. Concomitan neurological symptoms observed in a patient diagnosed with coronavirus disease 2019. J Med Virol. 2020.

25. Ye M, Ren Y, Lv T. Encephalitis as a clinical manifestation of COVID-19. Brain Behav Immun. 2020;S0889-1591(20)30465-7.

26. Carod-Artal FJ. Complicaciones neurológicas por coronavirus y $\mathrm{CO}$ VID-19. Rev Neurol. 2020;70:311-22.

27. Krishnan V, Leung LY, Caplan LR. A neurologist's approach to delirium: diagnosis and management of toxic metabolic encephalopathies. Eur $\mathrm{J}$ Intern Med. 2014;25:112-6.

28. Zubair AS, McAlpine LS, Gardin T, Farhadian S, Kuruvilla DE, Spudich $S$. Neuropathogenesis and neurologic manifestations of the coronaviruses in the age of coronavirus disease 2019: a review. JAMA Neurol. 2020 [Epub ahead of print].

29. Mehta P, McAuley DF, Brown M, Sanchez E, Tattersall RS, Manson JJ. COVID-19: consider cytokine storm syndromes and immunosuppression. Lancet. 2020;395:1033-4.

30. Filatov A, Sharma P, Hindi F, Espinosa PS. Neurological complications of coronavirus disease (COVID-19): encephalopathy. Cureus. 2020;12:e7352

31. Poyiadji N, Shahin G, Noujaim D, Stone M, Patel S, Griffith B. CO VID-19-Associated acute hemorrhagic necrotizing encephalopathy: CT and MRI features. Radiology. 2020;201187.

32. Rossi A. Imaging of acute disseminated encephalomyelitis. Neuroimaging Clin N Am. 2008;18:149-61.

33. Wang HY, Li XL, Yan ZR, Sun XP, Han J, Zhang BW. Potential neurological symptoms of COVID-19. Ther Adv Neurol Disord. 2020;13:1-2.

34. Wang $Y$, Wang $Y$, Chen $Y$, Qin $Q$. Unique epidemiological and clinical features of the emerging 2019 novel coronavirus pneumonia (COVID-19) implicate special control measures. J Med Virol. 2020 [Epub ahead of print].

35. Li Y, Wang M, Zhou Y, Chang J, Xian Y, Mao L, et al. Acute cerebrovascular disease following COVID-19: a single center, retrospective, observational study. SSRN Electron J. 2020 [Epub ahead of print].

36. Oxley TJ, Mocco J, Majidi S, Kellner CP, Shoirah H, Singh IP, et al. Large-vessel stroke as a presenting feature of covid-19 in the young. N Engl J Med. 2020;382:e60.
37. Sungnak W, Huang N, Bécavin C, Berg M, Queen R, Litvinukova M, et al. SARS-CoV-2 entry factors are highly expressed in nasal epithelial cells together with innate immune genes. Nat Med. 2020;26:681-7.

38. Marinosci A, Landis BN, Calmy A. Possible link between anosmia and COVID-19: sniffing out the truth. Eur Arch Otorhinolaryngol. 2020;77(7):2149-50.

39. Giacomelli A, Pezzati L, Conti F, Bernacchia D, Siano M, Oreni L, et al. Self-reported olfactory and taste disorders in SARS-CoV-2 patients: a cross-sectional study. Clin Infect Dis. 2020:ciaa330.

40. Lechien JR, Chiesa-Estomba CM, de Siati DR, Horoi M, Le Bon SD, Rodriguez $\mathrm{A}$, et al. Olfactory and gustatory dysfunctions as a clinical presentation of mild-to-moderate forms of the coronavirus disease (COVID-19): a multicenter European study. Eur Arch Otorhinolaryngol. 2020:1-11.

41. Xu H, Zhong L, Deng J, Peng J, Dan H, Zeng X, et al. High expression of ACE2 receptor of 2019-nCoV on the epithelial cells of oral mucosa. Int J Oral Sci. 2020;12:8.

42. Yamazato M, Ferreira AJ, Yamazato $Y$, Diez-Freire C, Yuan L, Gillies R, et al. Gene transfer of angiotensin-converting enzyme 2 in the nucleus tractus solitarius improves baroreceptor heart rate reflex in spontaneously hypertensive rats. J Renin Angiotensin Aldosterone Syst. 2011;12:456-61.

43. Toljan K. Letter to the editor regarding the viewpoint evidence of the COVID-19 virus targeting the CNS: tissue distribution, host-virus interaction, and proposed neurotropic mechanism. ACS Chem Neurosci. 2020;11:1192-4.

44. Zhao H, Shen D, Zhou H, Liu J, Chen S. Guillain-barré syndrome associated with SARS-CoV-2 infection: causality or coincidence? Lancet Neurol. 2020;19:383-4

45. Marta-Enguita J, Rubio-Baines I, Gastón-Zubimendi I. Síndrome de guillain-barré fatal tras infección por virus SARS-CoV2. Neurología. 2020;35:3.

46. Gutiérrez-Ortiz C, Méndez A, Rodrigo-Rey S, San Pedro-Murillo E, Bermejo-Guerrero L, Gordo-Mañas R, et al. Miller fisher syndrome and polyneuritis cranialis in COVID-19. Neurology. 2020 [Epub ahead of print].

47. Beh SC, Greenberg BM, Frohman T, Frohman EM. Transverse myelitis. Neurol Clin. 2013;31:79-138.

48. Zhao K, Huang J, Dai D, Feng Y, Liu L, Nie S. Acute myelitis after SARSCoV-2 infection: a case report. MedRxiv. 2020 [Epub ahead of print].

49. Zhai P, Ding Y, Wu X, Long J, Zhong Y, Li Y. The epidemiology, diagnosis and treatment of COVID-19. Int $J$ Antimicrob Agents. 2020:55:105955.

50. Protecting Healthcare Personnel. HAl/CDC; 2020. Available from: https:// www.cdc.gov/hai/prevent/ppe.html. [Last accessed on 2020 Jun 01].

51. Natoli S, Oliveira V, Calabresi P, Maia LF, Pisani A. Does SARS-Cov-2 invade the brain? Translational lessons from animal models. Eur J Neurol. 2020 [Epub ahead of print] 